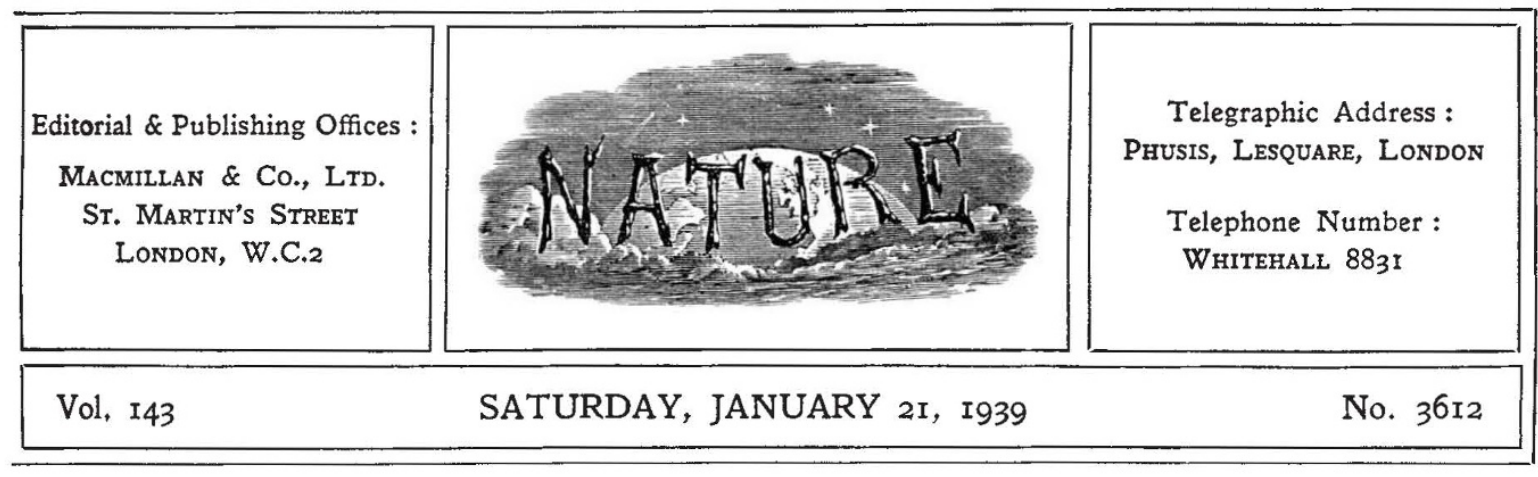

\title{
Planning for Constructive Defence
}

$\mathrm{T}$ HE stress rightly been laid in recent months upon moral rearmament is essentially the recognition that there must be some underlying moral basis and explicit code of values upon which wa can take our stand in working towards a more tolerable human society. In addition, however, we have been brought to realize the importance of visualizing the national economy and resources as a whole. The defence policy which is now imperative cannot be limited to the negative aspect of armaments and naval, military or air force organization. In addition, it must embrace positive effort devoted to removing causes of international friction and improving international relations, and also much of the work now directed to improving industrial efficiency, national health, social and economic conditions generally. It involves essentially industrial, social and economic strategy and tactics no less than naval or military strategy and tactics.

The dominant factor in determining this profound change has, of course, been the development of air transport as a weapon of war. In the face of this threat, the industrial cities of to-day have to develop the appropriate defensive measures in much the same way as the fortified city of the Middle Ages was developed to meet the military dangers of those days. The essential problem is indeed that of so planning our industrial, social and economic life as to secure adequate protection gainst sudden aggression, while preserving, under normal conditions, the maximum freedom of enterprise and activity consistent with rapid adjustment to the demands of a time of national emergency. We have to develop under the conditions of to-day a society that can mobilize in response to the threat of war as instantly and effectively as the burghers of the medieval town.
This aspect of planning was frankly recognized in the recent presidential address to the Town Planning Institute delivered by Mr. J. E. Acfield, who stressed the significance of the necessity of considering not only the risks of air attack but also those questions of location of industry, transport and the like which have to be taken into account in planning and may be equally determined by defence policy. He pointed out that the recent emergency had decisively emphasized the necessity for a National Advisory Board recommended in the report of the Town Planning Institute, and directed attention to the importance of recognizing trends in population occasioned not only by location of industry but also by changes in age distribution and the like due to the declining birth-rate. Similarly, a resolution on the planned control of the growth of London was moved by Sir Raymond Unwin at a conference of the Garden Cities and Town Planning Association. The resolution contemplates an authority which would control the location of new industries, preserve the remaining country within reach of London, guide development to existing smaller towns or well-designed new towns in the region and create a long-term plan for redevelopment in the centre. In discussing the project, Sir Raymond referred to the added urgency given to such problems by the necessity of protection from air raids, and the way in which planning could minimize risks.

The need for concerted policy in this matter of defence has been significantly enforced by investigations in widely different fields. Evidence submitted from time to time during the past year to the Royal Commission on the Distribution of the Industrial Population has indicated the necessity for some State control in this matter from the 
point of view of the most effective utilization of national resources, no less than from considerations of defence, and the report when it appears may well be expected to make some emphatic pronouncement on this point. The appointment of this Commission itself was largely due to the recommendation of Sir Malcolm Stewart's third report as Commissioner of the Special Areas, that the further expansion of industry in Greater London should be controlled to secure a more even distribution of production in which the Special Areas might share.

The same point of view has been taken by Sir Malcolm's successor, Sir George Gillett, who in his first report* insists that consideration of the social as well as of the economic effects of the transference of industries lies near the root of the problem of the Special Areas. In his view, the Government cannot, especially since the introduction of tariffs and quotas, evade all responsibility for the location of industry. Social and strategic, as well as economic, causes are fast impelling the abandonment of the laissez-faire doctrine in this matter.

Even more emphatically, however, have the events of the recent national emergency endorsed Sir Malcolm Stewart's argument about control of the location of industry in Greater London. The Committee on Evacuation was appointed in May 1938 , but the report itself was only published in Novembert, when the state of emergency was over. No reader of this report can be in any doubt as to the desirability of planning industrial location in future so as to diminish its vulnerability, or of the dangers to which unrestricted development in the past has now exposed us.

The difficulties with which evacuation is attended are made perfectly plain by the Committee, which considers that, none the less, the whole issue in any future war may well turn on the manner in which the problem of evacuation from densely populated areas is handled. Evacuation plans are no substitute for measures of active and passive defence, designed to enable production to be maintained in time of war in the industrial areas, but some measure of evacuation of non-essential persons from the principal industrial areas must be faced both on the grounds of humanity and to relieve the situation in congested industrial areas. * Report of the Commissioner for the Special Areas in England and
Wales for the Year ended 30th September, 1937. (Cmd. 5593.) Pp. xii +209. (London: H.M. Stationery Office, 1938.) 38. 6d. net.

+ Report of the Committee on Evacuation : with a Covering Memorandum by the Secretary of State for the Home Department. (Cmd.
5837 .) Pp. iv +39. (London: H.M. Stationery Office, 1938.) 98. net.
Indeed the country will not be fully prepared against attack until the necessary organization has been established and schemes of evacuation worked out.

In a covering memorandum to the report, the Home Secretary, Sir Samuel Hoare, indicates the Government's approval of the recommendations of the Committee and particularly its concurrence in the principle of voluntary but organized evacuation, as well as in that of accommodation of refugees under powers of compulsory billeting. While, however, the report clearly shows that a scheme based on these lines is perfectly practicable and that adequate transport facilities appear to exist, on many points of detail very much remains to be done, particularly in regard to billeting, if the anomalies and even absurdities exposed during the crisis of September last are to be avoided. Some. thing more than a mere count of houses or population is required if billeting is not to become farcical or even have alarming repercussions on the health of the community. Again, evacuation can only be regarded as a palliative, and the recognition of its present necessity should stimulate efforts directed to eliminate that necessity in future, whether by wiser location of industry or by the planning of towns and industrial areas so as to render them less vulnerable.

It should not be forgotten, moreover, that evacuation plans cannot be drawn up in isolation. They must form part of a considered and co-ordin. ated plan for national defence. Unless, for example, plans conceived in peace-time take into account the probable effect of emergency demands upon the population, not merely of the areas to be evacuated but also of those into which evacuation is to take place, the whole plan may break down at important points, or place intolerable strain upon particular localities or communities. Evacuation, in fact, must be considered with the Govern. ment's plan for a national register, whether voluntary or otherwise, which undoubtedly should yield important evidence to test the soundness of the evacuation plans in regard to district details. Moreover, man-power policy must involve more than the institution of a system even for securing the best utilization of the available resources in special skill and training or professional and technical knowledge. It must also have regard to measures which will ensure the continuance of the supply and that its quality is maintained.

From whatever angle therefore this question of national defence is approached, the supreme 
importance of a definite and co-ordinated national policy which takes account of all the factors involved and transcends sectional interests or prejudiced views is unmistakable. The danger at the present moment is that the impulse towards effective planning provided by the recent emergency may die out before it has been turned to tangible purpose. Further, in the absence of the elaboration and enactment of a definite policy of defence, private or sectional interests may embark on courses or policies which are inconsistent with the public good; while public authorities left without adequate guidance, whether they do nothing but continue along existing lines or follow some unsatisfactory line, may increase unwittingly the obstacles to the execution of a boldly conceived national plan.

Ir the face of this complex and difficult situation with its urgent call for a national plan, the opportunity which a defence policy affords for constructive effort should not be overlooked. National defence has qualitative as well as quantitative aspects. It must not merely provide against external threats to the existence of the nation. It must make positive contributions to its welfare. A policy for defence must take account of social welfare as well as of armament production and civil defence. National fitness in the widest sense is an indispensable element in national defence. Wisely conceived, a policy for defence will take account not only of physical training, nutrition, overcrowding, unemployment and other factors affecting the health of the nation. It will have regard also to many of the amenities of life which determine the mental and moral as well as the physical fitness of the people. Planning, whether civic or industrial, must be conceived not merely to provide more effective protection against attack and more efficient use of the man-power and material resources of the nation, but also to preserve the amenities of countryside, flora and fauna. It involves a land policy which will safeguard no less against the blunders of the past which have increased vulnerability than against the further destruction of national assets and amenities. It may well involve, too, an examination of the functions of local government and national administration and of the size of operating areas, if causes of inefficiency are to be eliminated and obstacles to a national policy overcome.

Nothing would indeed be more short-sighted than a policy for defence which restricted or warped educational development or those ideals of individual freedom of thought and criticism which are rightly cherished in a democracy. A defence policy must appeal to the highest ideals if it is to claim support, and for this reason alone it will be inadequate unless it offers also constructive effort towards international peace and good will, by working towards the removal of causes of international friction. Here indeed is work for education both within and without the frontiers of a State. The development of a national defence policy on such lines under the stress of the recent emergency may give us the stimulus to a plan and a concentrated effort which will overcome alike the obstacles and the threats which sectional or private interests have so long opposed in such diverse fields as road transport, building, town planning, national parks, nutrition and health to measures the desirability of which in the national interest has long been beyond dispute.

\section{British Agriculture}

\section{British Agriculture:}

the Principles of Future Policy. A Report of an Enquiry organized by Viscount Astor and B. Seebohm Rowntree. Pp. xx +469 . (London, New York and Toronto: Longmans, Green and Co., Ltd., 1938.) 15s. net.

THIS book is the report of an inquiry, organized by Viscount Astor and Mr. Seebohm Rowntree, into the economic structure of British agrioulture. It deals comprehensively with the main aspects of the agricultural problem, and although its chapters are rather unequal in quality, it provides a valuable addition to agricultural literature.

The volume is divided into five parts. In the first of these the authors examine the possibility of increasing agricultural production by curtailing imports. After considering the issues involved, they consider that protective measures should be limited so far as possible to securing reasonable stability for home producers and to averting 